\title{
PENINGKATAN KINERJA GURU MELALUI PENGEMBANGAN MOTIVASI KERJA DAN EFEKTIVITAS KOMUNIKASI ANTAR PRIBADI
}

\author{
Nancy Yusnita \\ Fakultas Ekonomi Universitas Pakuan \\ Email: nancyariadiningrat7@gmail.com
}

ARTICLE INFO

Article History

Received 23 Dec 2018

Revised 10 January 2019

Accepted 31 January 2019

JEL Classification

015

Kata kunci:

Kinerja Guru, Motivasi

Kerja, Efektivitas

Komunikasi Antar Pribadi

\section{ABSTRAK}

Penelitian ini bertujuan untuk menemukan upaya-upaya yang dapat dilakukan melalui analisis i hubungan antara motivasi kerja dan efektivitas komunikasi antar pribadi baik secara sendiri-sendiri maupun secara bersama-sama dengan kinerja guru Sekolah Dasar Negeri di Lingkungan Kecamatan Bogor Tengah. Penelitian ini merupakan penelitian korelasional yang terdiri atas dua variabel bebas yaitu motivasi kerja dan efektivitas komunikasi antar pribadi dan satu variabel terikat yaitu kinerja. Metode penelitian yang digunakan adalah metode survey yang dilaksanakan di 13 Sekolah Dasar Negeri di Lingkungan Kecamatan Bogor Tengah dengan responden terdiri dari 98 orang guru yang berstatus pegawai negeri sipil. Teknik pengambilan sampel dilakukan dengan menggunakan teknik sampel acak proporsional (proportional random sampling). Teknik analisis data menggunakan teknik korelasi dan regresi linier sederhana serta korelasi dan regresi ganda. Berdasarkan hasil penelitian ini, dapat dinyatakan bahwa peningkatan kinerja dapat dilakukan dengan cara meningkatkan motivasi kerja melalui peningkatan pada aspek: berorientasi pada tujuan; kegigihan menyelesaikan pekerjaan; usaha mencari umpan balik; harapan meraih keberhasilan; keterlibatan dengan tugas yang dikerjakan; kemauan mengembangkan diri serta pengembangan efektivitas komunikasi antar pribadi melalui peningkatan pada aspek: saling percaya; saling terbuka; tatap muka; saling menghargai; kejelasan pesan; umpan balik.

\section{Pendahuluan}

Di sebagian besar organisasi, kinerja karyawan merupakan faktor utama yang menentukan keberhasilan organisasional, seberapa baik karyawan melakukan pekerjaan mereka mempengaruhi kinerja organisasional secara signifikan. Kinerja karyawan, motivasi kerja dan komunikasi antar pribadi yang efektif merupakan faktor utama bagi organisasi untuk memaksimalkan efektivitas sumber daya manusia. Banyak faktoryang mempengaruhi kinerja karyawan diantara nya 
kemampuannya, usaha yang dicurahkan, dukungan organisasi yang diterimanya. Pengukuran kinerja menggunakan kriteria yang relevan yang berfokus pada aspek paling penting dari perkerjaan karyawan, sebagai contoh mengukur kinerja seorang tenaga kependidikan dari kemampuannya meyelenggarakan kegiatan belajar mengajar.

Kinerja yang tinggi disertai rasa tanggung jawab mesti menjadi ciri guru berkualitas. Dengan kinerja yang baik seorang guru akan tampil sebagai pembimbing (councelor), pelatih (coach) dan manajer pembelajaran (learning manager) yang mampu berinteraksi dengan siswa dalam proses transfer pengetahuan, ketrampilan dan nilai-nilai yang baik, yang pada akhirnya dapat menghasilkan output yang baik pula terutama meningkatkan hasil belajar siswa. Kinerja guru sangat penting dalam rangka peningkatan mutu pendidikan sehingga tuntutan akan kinerja guru semakin tinggi.

Agar sumber daya manusia dapat digerakkan dalam rangka mencapai tujuan organisasi maka perlu dipahami motivasi kerja guru. Pemberian motivasi kepala sekolah kepada guru maupun motivasi yang timbul dari diri guru sendiri untuk bekerja akan mampu mencapai kinerja organisasi yang maksimal dan tercapainya tujuan organisasi.

Karakteristik individu yang berbeda jenis kebutuhan, sikap dan minat menimbulkan motivasi yang bervariasi, misalnya pegawai yang mempunyai motivasi untuk mendapatkan uang sebanyak-banyaknya akan bekerja keras dengan resiko tinggi dibanding dengan pegawai yang mempunyai motivasi keselamatan, dan akan berbeda pada pegawai yang bermotivasi untuk memperoleh prestasi.

Suatu penelitian menunjukkan bahwa komunikasi yang kurang efektif paling sering disebut sebagai sumber konflik antar pribadi. Para individu menghabiskan hampir $70 \%$ dari waktu terjaganya untuk berkomunikasi yaitu menulis, membaca, berbicara dan mendengarkan. Dapat diduga salah satu kekuatan yang paling menghambat suksesnya $\mathrm{k} \quad$ inerja kelompok adalah komunikasi yang kurang efektif.

Komunikasi yang baik dapat menciptakan suasana kerja yang nyaman yang memungkinkan setiap anggota organisasi dapat bekerja dan bekerjasama dengan baik. Dalam hal ini dengan terciptanya komunikasi yang lancar baik secara horizontal maupun vertikal antar anggota sekolah maka diharapkan seorang guru dapat merasakan kenyamanan dalam bekerja yang pada akhirnya dapat meningkatkan kinerja secara optimal. Komunikasi antar pribadi guru dapat berbentuk bertanya kepada guru berpengalaman, sehingga pengetahuan guru menjadi bertambah dan hasil kerjanya meningkat. Dalam hal ini, komunikasi adalah proses penyampaian informasi. Komunikasi dapat dikatakan berhasil apabila ada pentransferan dan pemahaman makna dari satu orang ke orang lain. Suatu gagasan betapapun besarnya, tidak akan berguna sebelum diteruskan dan dipahami orang lain.

Dewasa ini banyak faktor yang diduga berkaitan dengan permasalahan yang dihadapi guru di Indonesia antara lain, masalah kualitas/mutu guru, jumlah guru yang dirasakan masih kurang, masalah distribusi guru danmasalah kesejahteraan guru. Hal tersebut dapat mempengaruhi kinerja guru.

Semangat kerja yang tinggi memberi kesetiaan, kegembiraan, ketaatan pada kewajiban, disiplin, inisiatif, dan kebanggaan terhadap sekolah. Seorang guru akan lebih bersemangat bila mengetahui pekerjaan yang dilakukan mempunyai arti penting dan menarik perhatian. Sebagai contoh seorang guru akan lebih bersemangat dalam melakukan pekerjaan apabila mereka mendapatkan pengawasan dari kepala sekolah, fasilitas dan penghargaan kerja sesuai dengan apa yang mereka berikan kepada sekolah.

Salah satu kunci keberhasilan sekolah terletak pada efisiensi dan efektivitasnya 
penampilan seorang kepala sekolah. Betapa perlunya kualitas pemimpin, maka selalu ditekankan pentingnya kemampuan dasar yang perlu dimiliki oleh kepala sekolah yaitu: sebagai kader akan tercermin sifat-sifat: jujur, percaya diri, tanggung jawab, berani mengambil resiko dan keputusan, berjiwa besar, emosi yang stabil dan teladan pada guru dan elemen-elemen sekolah. Kepala sekolah juga harus mampu mengembangkan guru untuk tumbuh dalam kepemimpinannya. Kepala sekolah bukan hanya berfungsi sebagai kepala tetapi juga sebagai seorang pemimpin yang mendorong peningkatan kinerja guru.

Kondisi lingkungan kerja yang terlihat dalam semangat atau gairah kerja yang menghasilkan kegiatan kerja sebagai kontribusi bagi tercapainya tujuan organisasi dipengaruhi pula oleh fasilitas kerja, karena dengan fasilitas kerja yang tersedia dapat memudahkan dan memperlancar pelaksanaan pekerjaan kegiatan belajar mengajar, sehingga kinerja guru meningkat.

Dengan berbagai permasalahan di atas maka guru menjadi salah satu faktor menentukan dalam konteks meningkatkan mutu pendidikan dan menciptakan sumber daya manusia yang berkualitas karena guru adalah garda terdepan yang berhadapan langsung dan berinteraksi dengan siswa dalam proses belajar mengajar. Mutu pendidikan yang baik dapat dicapai dengan guru yang profesional dengan segala kompetensi yang dimiliki

\section{KAJIAN LITERATUR Hakikat Kinerja}

Bernardin dan Rusel dalam Achmad Ruky (2002) memberikan definisi tentang kinerja (performance) sebagai berikut : "Performance is defined as the record of autcomes produced on a specified job function or activity during a specified time period "(kinerja adalah catatan tentang hasil-hasil yang diperoleh dari fungsifungsi pekerjaan tertentu atau kegiatan tertentu selama kurun waktu tertentu).
Definisi ini menekankan kinerja sebagai hasil atau apa yang keluar (outcome) dari sebuah pekerjaan dan kontribusi pegawai terhadap organisasi.

Mathis dan Jackson (2006), bahwa kinerja (performance) pada dasarnya adalah apa yang dilakukan oleh karyawan yang meliputi elemen kuantitas dari hasil, kualitias dari hasil, ketepatan waktu dari hasil, kehadiran dan kemampuan bekerjasama.

Wood et.al (2001), bahwa Performance is a summary measure of the quantity and quality of task contributions made by individual and group to the work unit and organization

Wirawan (2009) mendefinisikan kinerja sebagai keluaran yang dihasilkan oleh fungsifungsi atau indikator-indikator suatu pekerjaan atau suatu profesi dalam waktu tertentu.

Hadari Nawawi (2006), kinerja dapat diartikan sebagai apa yang dikerjakan (hasil kerja) seorang karyawan dalam melaksanakan tugastugas pokoknya. Dalam pengertian praktis berarti indikator kinerja dalam melaksanakan pekerjaan pada sebuah organisasi yang mencakup lima unsur yaitu kuantitas hasil kerja yang dicapai, kualitas hasil kerja yang dicapai, jangka waktu mencapai hasil kerja tersebut, kehadiran dan kegiatan selama hadir di tempat kerja dan kemampuan bekerja sama.

\section{Hakikat Motivasi Kerja}

Gibson et al (2006) "motivation is forces acting on an employee that initiate and direct behavior. This concept explain differences in the intensity of behavior regarding more intense behavior as result of higher levels of motivation and also to indicate the direction of behavior"

Rue and Byars mendefinisikan (2007) "Motivation means getting people to exert a 
high degree of effort on their job. Motivation is something that must come from within an employee. Motivation can be understood using sequences: needs, drive or motives, accomplishment of goals"

Kreitner dan Kinicki (2008) "Motivation can be define as the psychological process that arouse and direct goal-directed behavior. The model of how it works is that people have certain needs that motivate them to perform specific behaviors for which they receive rewards, both extrinsic and intrinsic, that feed back and satisfy the original need. The three major perspectives on motivation are need-based, process, and reinforcement"

Motivasi menurut Robbins (2002) adalah dorongan dari dalam diri individu, dengan ciri 1) bertanggung jawab; 2) berusaha memperoleh umpan balik; 3) berani mengambil resiko moderat.

Mc.Clelland dalam Miftah Thoha (2006) tentang Needs For Achievement yang menyatakan bahwa motivasi berbeda-beda sesuai dengan kebutuhan seseorang. Ada tiga kebutuhan manusia yakni kebutuhan untuk berprestasi, kebutuhuan untuk berafiliasi dan kebutuhan untuk kekuasaan. Beberapa karakteristik orang bermotivasi antara lain 1) suka mengambil resiko yang moderat; 2) memerlukan umpan balik yang segera; 3) memperhitungkan keberhasilan; 4) menyatu dengan tugas

\section{Hakikat Efektivitas Komunikasi Antar Pribadi} Kinicki dan Wiliams (2008) "Communication is the transfer of information and understanding from one person to another. The process involves sender, message, and receiver; encoding and decoding; the medium feedback; and dealing with "noise" or interference. Managers need to tailor their communication to appropriate medium (rich or lean) for the appropriate situation"
Rue dan Byars (2007) mendefinisikan, "Communication is the act of exchanging information. It can be used to inform, command, instruct, assess, influence, and persuade other people. Communication skill are important in all aspect of life, including business/

Robbins (2006), komunikasi adalah penyampaian dan pemahaman makna. Komunikasi yang sempurna adalah bila pikiran atau ide yang disampaikan dipersepsikan individu penerima persis sama dengan yang digambarkan oleh individu pengirim. Komunikasi menjalankan empat fungsi utama yaitu pengendalian, motivasi, pengungkapan emosi dan informasi yang mana kombinasi keempat faktor tesebut dapat mempengaruhi kinerja individu. Proses komunikasi meliputi 1) sumber komunikasi; 2) pengkodean; 3) pesan; 4) saluran; 5) decoding; 6) penerima; 7) umpan balik yang berlangsung antar pribadi.

De Janasz et.al (2009). mendefinisikan, "Communication is the imparting, conveying, or exchange of ideas, knowledge, information, and the like by means of mechanical or electronic speech, writing or signs.

Gibson et al (2006), "Communication defined as the transmission of information and understanding through the use of common symbols. The common symbols may be verbal or nonverbal.

Adam I. Angkawijaya (2000) komunikasi adalah penyampaian makna. Komunikasi yang efektif memerlukan informasi dan pengertian. Untuk itu ada empat unsur yang meliputi 1) perhatian (attention) adalah pengirim maupun yang akan menerima siap untuk melakukan komunikasi; 2) pengertian (understanding) adalah yang menerima dapat menangkap maksud sesungguhnya pesan yang disampaikan; 3) penerimaan (acceptance) 
adalah penerima diharapkan bersedia melakukan isi dan pesan yang diterimanya dan 4) tindakan (action) adalah suatu komunikasi menjadi operasional atau menjadi kenyataan.

Rogers dan Kincaid dalam Wiryanto (2004) menyatakan bahwa komunikasi adalah suatu proses dimana dua atau lebih membentuk atau melakukan pertukaran informasi antara satu sama lain, yang pada gilirannya terjadi saling pengertian yang mendalam.

Rue dan Byars (2007) mendefinisikan Interpersonal Communication is an interactive process between individuals that involves sending and receiving verbal and nonverbal messages. The basic purpose of interpersonal communication is to transmit information so that the sender of message is understood by receiver of the message.

Drucker dalam Thoha (2002) mengungkapkan komunikasi antar pribadi adalah proses penyampaian berita yang dilakukan oleh seseorang dan diterima nya berita tersebut oleh orang lain atau kelompok kecil dan orangorang, dengan suatu akibat dan umpan balik yang segera. Komunikasi antar pribadi ini berorientasi pada perilaku, sehingga penekanannya pada proses penyampaian informasi dari satu orang ke orang lain. Banyak keterampilan yang diperlukan untuk menjadikan interaksi antar pribadi berhasil yaitu penggunaan komunikasi non-verbal yang efektif, keterbukaan dalam memberikan ide, kemampuan memberikan petunjuk dengan jelas, wawasan pengetahuan dan perasaan kebersamaan.

\section{METODOLOGI PENELITIAN}

Metode yang dilakukan dalam penelitian ini adalah metode survey dengan pendekatan korelasional. Penelitian ini merupakan upaya untuk menggambarkan beberapa variabel yang menyangkut pengaruh motivasi kerja, efektivitas komunikasi antar pribadi dan kinerja guru pegawai negeri sipil (PNS) pada Sekolah Dasar Kecamatan Bogor Tengah Kota Bogor.

Alat ukur (instrumen) yang digunakan dari semua variabel yang diteliti baik kinerja guru, motivasi kerja, maupun efektivitas komunikasi antar pribadi adalah angket (questionnaire) yaitu berupa daftar pernyataan yang diberikan kepada responden sesuai dengan sampel yang telah ditentukan. Angket atau kuesioner pada penelitian ini adalah angket tertutup yaitu angket yang jawabannya sudah disediakan sehingga responden tinggal memilih satu jawaban yang sesuai dengan pendapat dirinya.

Adapun tahap penelitian diawali dengan pembuatan instrumen penelitian. Selanjutnya dilakukan pengujian terhadap instrumen tersebut dengsn menggunakan metode statistik. Setelah mendapatkan instrumen yang valid dan reliable maka tahapan selanjutnya adalah berupa penyebaran instrumen kepada sampel.

\section{Populasi dan Sampel Penelitian}

1. Populasi penelitian

Populasi dalam penelitian ini adalah para guru yang berstatus pegawai negeri sipil (PNS) dan menjabat sebagai guru kelas di Sekolah Dasar Negeri di Kecamatan Bogor Tengah, Kota Bogor. Populasi yang terjangkau berjumlah 130 orang guru.

2. Teknik Pengambilan Sampel

Sampel adalah representasi dari guru-guru yang tersebar di 13 Sekolah Dasar Negeri di Kecamatan Bogor Tengah Kota Bogor. Yang diambil dengan menggunakan rumus slovin maka didapat 98 orang responden dari 130 orang populasi guru. 
Tabel 1. Pengambilan Sample Proporsional Random Sampling

\begin{tabular}{|c|l|c|l|c|}
\hline No & \multicolumn{1}{|c|}{ Nama Sekolah } & $\begin{array}{c}\text { Jumlah } \\
\text { Guru }\end{array}$ & Pengambilan Sampel & Dibulatkan \\
\hline 1 & SDN Pengadilan 2 & 12 & $12 / 130 \times 98=9,05$ & 9 \\
\hline 2 & SDN Polisi 1 & 9 & $9 / 130 \times 98=6,78$ & 7 \\
\hline 3 & SDN Polisi 4 & 15 & $15 / 130 \times 98=11,31$ & 12 \\
\hline 4 & SDN Polisi 5 & 13 & $13 / 130 \times 98=9,8$ & 10 \\
\hline 5 & SDN Panaragan 1 & 12 & $12 / 130 \times 98=9,04$ & 9 \\
\hline 6 & SDN Gunung Gede & 11 & $11 / 130 \times 98=8,29$ & 8 \\
\hline 7 & SDN Babakan & 12 & $12 / 130 \times 98=9,05$ & 9 \\
\hline 8 & SDN Baranangsiang & 9 & $9 / 130 \times 98=6,78$ & 7 \\
\hline 9 & SDN Malabar 1 & 7 & $7 / 130 \times 98=5,27$ & 5 \\
\hline 10 & SDN Papandayan 3 & 7 & $7 / 130 \times 98=5,27$ & 5 \\
\hline 11 & SDN Empang 3 & 7 & $7 / 130 \times 98=5,27$ & 5 \\
\hline 12 & SDN Empang 4 & 8 & $8 / 130 \times 98=6,03$ & 6 \\
\hline 13 & SDN Gang Aut & 8 & $8 / 130 \times 98=6,03$ & 6 \\
\hline \multicolumn{1}{r}{ Jumlah } & 130 & & 98 \\
\hline
\end{tabular}

\section{Teknik Pengumpulan Data}

1. Instrumen Kinerja

a. Definisi Konseptual

Kinerja adalah hasil kerja yang diperlihatkan seorang individu dalam melaksanakan tugasnya untuk mencapai tujuan organisasi dalam kurun waktu tertentu.

b. Definisi Operasional

Hasil kerja yang diperlihatkan seorang individu yang diukur dengan menggunakan instrument penelitian ini berdasarkan indikator : 1) Kuantitas hasil kerja ; 2) Kualitas hasil kerja ; 3) Waktu penyelesaian pekerjaan ; 4) Pencapaian standar kerja ; 5) Tanggung jawab terhadap pekerjaan. Indikator tersebut dipakai untuk menyusun kuesioner yang menggunakan Rating Scale Method,

2. Instrumen Motivasi Kerja

a. Definisi Konseptual

Motivasi kerja adalah dorongan, daya penggerak atau kekuatan yang terdapat dalam diri seseorang yang menyebabkan dan mengarahkan individu untuk berprilaku guna memenuhi kebutuhannya.

b. Definisi Operasional

Dorongan, daya penggerak atau kekuatan yang terdapat dalam diri seseorang yang diukur dengan instrumen penelitian ini berdasarkan indikator: 1) Berorientasi pada tujuan; 2) Kegigihan menyelesaikan pekerjaan; 3) Usaha mencari umpan balik; 4) Harapan meraih keberhasilan; 5) Keterlibatan dengan tugas yang dikerjakan; dan 6) Kemauan mengembangkan diri.

Indikator tersebut dipakai untuk menyusun kuesioner yang menggunakan Likert Scale.

3. Instrumen Efektivitas Komunikasi Antar Pribadi

a. Definisi Konseptual

Efektivitas komunikasi antar pribadi ini adalah taraf ketepatan sasaran dari proses penyampaian pesan atau informasi diantara individu dengan menggunakan simbol-simbol yang dapat 
berupa verbal maupun non verbal secara tatap muka.

b. Definisi Operasional

Taraf ketepatan sasaran dari proses penyampaian pesan atau informasi diantara individu yang diukur dengan instrumen penelitian ini berdasarkan indikator: 1) Saling percaya; 2) Saling terbuka; 3) Tatap muka; 4) Saling menghargai ; 5) Kejelasan pesan; dan 6) Umpan balik.

Indikator tersebut dipakai untuk menyusun kuesioner yang menggunakan Rating Scale Method.

\section{HASIL PENELITIAN}

Hubungan Antara Motivasi Kerja $\left(X_{1}\right)$ dengan Kinerja ( $Y$ )

HO: $\rho_{y .1}=0$ Tidak terdapat hubungan Motivasi Kerja dengan Kinerja.

H1: $\rho_{y .1}>0$ Terdapat hubungan positif Motivasi Kerja dengan Kinerja.

Perumusan hipotesis pertama pada penelitian ini adalah terdapat hubungan positif antara Motivasi $\left(X_{1}\right)$ dengan Kinerja $(Y)$. Setelah dilakukan pengujian persyaratan analisa melalui uji normalitas, homogenitas dan linieritas didapatkan perhitungan hubungan fungsional atas kedua variabel Motivasi $\left(X_{1}\right)$ dengan Kinerja $(Y)$ diperoleh hasil sebagai berikut:

1. Sesuai dengan hipotesis statistik maka hubungan antara Motivasi Kerja dengan Kinerja berdasarkan perhitungan dengan menggunakan teknik korelasi product moment diperoleh koefisien korelasi $r_{\mathrm{y} .1}=$ $0,656\left(r_{\text {tabel }}=0,195\right.$ pada $\alpha=0,05$ dan $r_{\text {tabel }}$ $=0,254$ pada $\alpha=0,01)$. $r_{\text {hitung }}>r_{\text {tabel, }}$ dengan demikian $\mathrm{H}_{0}$ ditolak dan $\mathrm{H}_{1}$ diterima, berarti terdapat hubungan positif yang sangat signifikan antara Motivasi Kerja $\left(\mathrm{X}_{1}\right)$ dengan Kinerja (Y).

2. Kontribusi Motivasi Kerja $\left(X_{1}\right)$ terhadap Kinerja $(\mathrm{Y})$ dihitung berdasarkan koefisien determinasi yaitu $r^{2}=\left(r_{y .1}\right)^{2}=0,43$. Berarti
Motivasi Kerja membentuk kontribusi sebesar $43 \%$ terhadap Kinerja.

3. Hubungan fungsional antara Motivasi Kerja dengan Kinerja dihitung menggunakan teknik analisis regresi, $\hat{Y}=82+0,69 \mathrm{X}_{1}$. Dari pengujian signifikan persamaan regresi diperoleh kesimpulan bahwa $F_{\text {hitung }}=0,52$ $\left(F_{\text {tabel }}=3,94\right.$ pada $\alpha=0,05$ dan $F_{\text {tabel }}=6,90$ pada $\alpha=0,01) \quad F_{\text {hitung }}>F_{\text {tabel }}$ berarti persamaan regresi tersebut sangat signifikan dengan demikian Motivasi Kerja dapat digunakan untuk memprediksi Kinerja.

Hubungan antara Efektivitas Komunikasi Antar Pribadi $\left(\mathrm{X}_{2}\right)$ dengan Kinerja $(\mathrm{Y})$

HO: $\rho_{y .2}=0$ Tidak terdapat hubungan Efektivitas Komunikasi Antar Pribadi dengan Kinerja.

H1: $\rho_{y .2}>0$ Terdapat hubungan positif Efektivitas Komunikasi Antar Pribadi dengan Kinerja.

Perumusan hipotesis kedua pada penelitian ini adalah terdapat hubungan positif antara Efektivitas Komunikasi Antar Pribadi ( $\left.\mathrm{X}_{2}\right)$ dengan Kinerja (Y). Setelah dilakukan pengujian persyaratan analisa melalui uji normalitas, homogenitas dan linieritas didapatkan perhitungan hubungan fungsional atas kedua variabel Efektivitas Komunikasi Antar Pribadi $\left(\mathrm{X}_{2}\right)$ dengan Kinerja $(\mathrm{Y})$ diperoleh hasil sebagai berikut:

1. Sesuai dengan hipotesis statistik maka hubungan antara Efektivitas Komunikasi Antar Pribadi dengan Kinerja berdasarkan perhitungan dengan menggunakan teknik korelasi product moment diperoleh koefisien korelasi $r_{\mathrm{y} .2}=0,577\left(r_{\text {tabel }}=0,195\right.$ pada $\alpha=0,05$ dan $r_{\text {tabel }}=0,254$ pada $\alpha=$ $0,01)$. $\quad r_{\text {hitung }}>r_{\text {tabel }}$, dengan demikian $H_{0}$ ditolak dan $\mathrm{H}_{1}$ diterima, berarti terdapat hubungan positif yang sangat signifikan antara Efektivitas Komunikasi Antar Pribadi $\left(\mathrm{X}_{2}\right)$ dengan Kinerja $(\mathrm{Y})$.

2. Kontribusi Efektivitas Komunikasi Antar Pribadi $\left(\mathrm{X}_{2}\right)$ terhadap Kinerja $(\mathrm{Y})$ dihitung 
berdasarkan koefisien determinasi yaitu $r^{2}$ $=\left(r_{y .2}\right)^{2}=0,33$. Berarti Efektivitas Komunikasi Antar Pribadi membentuk kontribusi sebesar 33\% terhadap Kinerja.

3. Hubungan fungsional antara Efektivitas Komunikasi Antar Pribadi dengan Kinerja dihitung menggunakan teknik analisis regresi $\hat{Y}=62,65+0,86 X_{2}$. Pengujian signifikan persamaan regresi diperoleh kesimpulan bahwa $\mathrm{F}_{\text {hitung }}=48,02\left(\mathrm{~F}_{\text {tabel }}=\right.$ 3,94 pada $\alpha=0,05$ dan $F_{\text {tabel }}=6,90$ pada $\alpha=$ $0,01)$. $F_{\text {hitung }}>F_{\text {tabel, }}$ berarti persamaan regresi tersebut sangat signifikan dengan demikian Efektivitas Komunikasi Antar Pribadi dapat digunakan untuk memprediksi Kinerja.

Hubungan antara Motivasi Kerja $\left(X_{1}\right)$ dan Efektivitas Komunikasi Antar Pribadi $\left(X_{2}\right)$ secara bersama dengan Kinerja $(Y)$.

HO: $\rho_{y 1.2}=0$ Tidak terdapat hubungan Motivasi Kerja dan Efektivitas Komunikasi Antar Pribadi dengan Kinerja.

H1: $\rho_{y 1.2}>0$ Terdapat hubungan positif Motivasi Kerja dan Efektivitas Komunikasi Antar Pribadi secara bersama-sama dengan Kinerja.

Hipotesis ketiga yang diujikan adalah terdapatnya hubungan positif Motivasi Kerja $\left(X_{1}\right)$ dan Efektivitas Komunikasi Antar Pribadi $\left(X_{2}\right)$ secara bersama-sama dengan Kinerja $(Y)$.

1. Sesuai dengan hipotesis statistik maka hubungan antara Motivasi Kerja $\left(X_{1}\right)$ dan Efektivitas Komunikasi Antar Pribadi $\left(\mathrm{X}_{2}\right)$ secara bersama-sama dengan Kinerja $(Y)$ berdasarkan perhitungan dengan menggunakan teknik korelasi product moment diperoleh koefisien korelasi $r_{y .1 .2}=$ $0,712\left(r_{\text {tabel }}=0,195\right.$ pada $\alpha=0,05$ dan $r_{\text {tabel }}$ $=0,254$ pada $\alpha=0,01)$. $\quad r_{\text {hitung }}>r_{\text {tabel, }}$ dengan demikian $\mathrm{H}_{0}$ ditolak dan $\mathrm{H}_{1}$ diterima, berarti terdapat hubungan positif yang sangat signifikan antara Motivasi Kerja $\left(\mathrm{X}_{1}\right)$ dan Efektivitas Komunikasi Antar
Pribadi $\left(X_{2}\right)$ secara bersama-sama dengan Kinerja $(\mathrm{Y})$.

2. Kontribusi Motivasi Kerja $\left(X_{1}\right)$ dan Efektivitas Komunikasi Antar Pribadi $\left(X_{2}\right)$ secara bersama-sama dengan Kinerja $(\mathrm{Y})$ dihitung berdasarkan koefisien determinasi yaitu $r^{2}=\left(r_{y .1 .2}\right)^{2}=0,507$. Berarti Motivasi Kerja dan Efektivitas Komunikasi Antar Pribadi membentuk kontribusi sebesar 50,7\% terhadap Kinerja.

3. Hubungan fungsional antara Motivasi Kerja $\left(X_{1}\right)$ dan Efektivitas Komunikasi Antar Pribadi $\left(X_{2}\right)$ secara bersama-sama dengan Kinerja $(Y)$ dihitung menggunakan teknik analisis regresi $\hat{Y}=33,72+0,52 X_{1}+0,48 X_{2}$. Pengujian signifikan persamaan regresi diperoleh kesimpulan bahwa $F_{\text {hitung }}=48,79$ $>F_{\text {tabel }}\left(F_{\text {tabel }}=3,09\right.$ pada $\alpha=0,05$ dan $F_{\text {tabel }}=$ $4,82$ pada $\alpha=0,01)$. Berarti persamaan regresi tersebut sangat signifikan dengan demikian Motivasi Kerja dan Efektivitas Komunikasi Antar Pribadi dapat digunakan untuk memprediksi Kinerja.

\section{PENUTUP \\ SIMPULAN}

Hasil penelitian yang dilakukan pada guru-guru sekolah dasar Negeri di lingkungan Kecamatan Bogor Tengah yang berstatus Pegawai Negeri Sipil (PNS) sebagai unit analisisnya menghasilkan kesimpulan sebagai berikut:

1. Terdapat hubungan positif yang kuat dan sangat signifikan antara motivasi kerja dengan kinerja dengan koefisien korelasi $r_{y .1}=0,656$ pada $\alpha=0,05$ dan $\alpha=0,01$, dan didukung pula dengan persamaan regresi $\hat{Y}$ $=82+0,69 X_{1}$ yang signifikan artinya semakin tinggi motivasi kerja maka diprediksi kinerja guru-guru sekolah dasar Negeri di lingkungan Kecamatan Bogor Tengah semakin tinggi. Hasil penelitian juga menunjukkan nilai koefisien determinasi $\left(r_{y .1}\right)^{2}=0,43$ yang berarti kinerja dapat dijelaskan oleh motivasi kerja sebesar $43 \%$. Hal ini menunjukkan motivasi kerja 
memberikan kontribusi yang besar terhadap kinerja guru.

2. Terdapat hubungan positif yang kuat dan sangat signifikan antara efektivitas komunikasi antar pribadi dengan kinerja dengan koefisien korelasi ry.2 $=0,58$ pada $\alpha=0,05$ dan $\alpha=0,01$, dan didukung pula persamaan regresi $\hat{Y}=62,65+0,86_{\times 2}$ artinya semakin tinggi efektivitas komunikasi antar pribadi maka diprediksi kinerja guru-guru sekolah dasar Negeri di lingkungan Kecamatan Bogor Tengah semakin tinggi.. Hasil penelitian juga menunjukkan nilai koefisien determinasi $(\text { ry. } 2)^{2}=0,33$ yang berarti kinerja dapat dijelaskan oleh efektivitas komunikasi antar pribadi sebesar 33\%. Hal ini menunjukkan bahwa efektivitas komunikasi antar pribadi memberikan kontribusi yang cukup berarti kepada kinerja guru.

3. Terdapat hubungan positif yang kuat dan sangat signifikan antara motivasi kerja dan efektivitas komunikasi antar pribadi secara bersama-sama dengan kinerja dengan koefisien korelasi $r_{y \cdot 1.2}=0,712$ pada $\alpha=0,05$ dan $\alpha=0,01$, dengan persamaan regresi $\hat{Y}=$ $33,72+0,52 X_{1}+0,48 \quad X_{2}$ artinya semakin tinggi motivasi kerja dan efektivitas komunikasi antar pribadi maka diprediksi kinerja guru-guru sekolah dasar Negeri di lingkungan Kecamatan Bogor Tengah semakin tinggi. Hasil penelitian juga menunjukkan nilai koefisien determinasi $r^{2}$ $=\left(r_{y .1 .2}\right)^{2}=0,507$ yang berarti kinerja dapat dijelaskan oleh motivasi kerja dan efektivitas komunikasi antar pribadi sebesar $50,7 \%$. Hal ini menunjukkan bahwa motivasi kerja dan efektivitas komunikasi antar pribadi memberikan kontribusi yang cukup besar kepada kinerja guru.

\section{IMPLIKASI}

Kinerja adalah hasil kerja yang diperlihatkan seorang individu dalam melaksanakan tugasnya untuk mencapai tujuan organisasi dalam kurun waktu tertentu.
Ciri-ciri individu yang memiliki kinerja tinggi dapat dinilai dari kuantitas hasil kerja, kualitas hasil kerja, waktu penyelesaian pekerjaan, pencapaian standar kerja serta tanggung jawab terhadap pekerjaan.

Masalah peningkatan kinerja adalah masalah yang komplek karena melibatkan berbagai faktor. Dua faktor yang mempengaruhi kinerja diantaranya adalah motivasi kerja dan efektivitas komunikasi antar pribadi. Tinggi rendahnya motivasi sorang individu dapat diukur dengan indikator: berorientasi pada tujuan, kegigihan menyelesaikan pekerjaan, usaha mencapai umpan balik, harapan meraih keberhasilan, keterlibatan dengan tugas yang dikerjakan, kemauan mengembangkan diri. Individu yang memiliki motivasi tinggi akan berusaha untuk memberikan yang terbaik yang bisa dilakukannya,untuk mencapai tujuan yang diharapkannya.

Komunikasi adalah proses penyampaian informasi. Komunikasi dapat dikatakan berhasil apabila ada pentransferan dan pemahaman makna dari satu orang ke orang lain dengan menggunakan simbol-simbol yang dapat berupa verbal maupun non verbal. Suatu gagasan betapapun besarnya, tidak akan berguna sebelum diteruskan dan dipahami orang lain. Komunikasi yang sempurna akan muncul bila pikiran atau ide disampaikan sehingga gambaran mental yang dipersepsikan penerima persis sama dengan yang dibayangkan oleh pengirim. Taraf keefektifan komunikasi antar pribadi dapat diukur dengan indikator saling percaya, saling terbuka, tatap muka, saling menghargai, kejelasan pesan, umpan balik dari penerima.

Bila seorang individu memiliki motivasi kerja yang tinggi maka individu tersebut akan mengerahkan segenap kemampuannya untuk mencapai target kerja yang telah ditetapkan yang tentunya akan meningkatkan kinerja guru. Begitu pula dengan komunikasi antar pribadi yang efektif maka akan terjadi komunikasi dua arah yang 
terjalin dengan baik dan saling pengertian, tidak akan terjadi lagi miss communication tentunya hal ini pada akhirnya akan meningkatkan Kinerja. Hal ini menunjukkan motivasi kerja dan efektivitas komunikasi antar pribadi mempunyai peranan yang besar dalam konteks manajemen Kinerja guru dan peningkatan kinerja guru.

Berdasarkan uraian di atas yang dilandasi oleh hasil penelitian mengenai motivasi kerja dan efektivitas komunikasi antar pribadi dengan kinerja maka dapat ditarik kesimpulan bahwa salah satu usaha untuk meningkatkan kinerja adalah dengan peningkatan motivasi kerja dan juga peningkatan efektivitas komunikasi antar pribadi.

1. Upaya Peningkatan Motivasi Kerja dalam Hubungannya dengan Kinerja pada guru Sekolah Dasar Negeri di Lingkungan Kecamatan Bogor Tengah

Untuk lebih meningkatkan kinerja guru Sekolah Dasar di Lingkungan Kecamatan Bogor Tengah maka hal yang perlu dilakukan adalah dengan cara meningkatkan motivasi kerjanya. motivasi kerja yang tinggi dapat meningkatkan kepuasan kerja yang tinggi pula yang pada gilirannya akan meningkatkan kinerja guru.

Motivasi kerja adalah dorongan, daya penggerak atau kekuatan yang terdapat dalam diri seseorang yang menyebabkan dan mengarahkan individu untuk berprilaku guna memenuhi kebutuhannya. Dengan memiliki arah adan tujuan yang jelas maka seorang guru tidak lagi mengalami kebingungan dalam menjalankan tugas dan fungsinya. Seorang guru harus mampu meingkatkan motivasi kerjanya karena semakin tinggi motivasi kerja maka akan semakin tinggi pula kinerjanya. Demikian pula sebalikya semakin rendah motivasi kerja maka akan semakin rendah pula kinerjanya. Upaya yang dapat dilakukan untuk meningkatkan kinerja melalui motivasi dapar dilakukan dengan cara meningkatkan pengetahuan dan keterampilan untuk menunjang proses transformasi kepada siswa dengan cara guru diikutkan pada training yang berhubungan dengan profesi guru.

2. Upaya Peningkatan Efektivitas Komunikasi Antar Pribadi dalam Hubungannya dengan Kinerja pada guru Sekolah Dasar Negeri di Lingkungan Kecamatan Bogor Tengah

Untuk lebih meningkatkan kinerja guru Sekolah Dasar di Lingkungan Kecamatan Bogor Tengah maka hal yang perlu dilakukan adalah dengan cara meningkatkan efektivitas komunikasi antar pribadi. Efektivitas komunikasi antar pribadi adalah taraf ketepatan sasaran dari proses penyampaian pesan atau informasi diantara individu dengan menggunakan simbol-simbol yang dapat berupa verbal maupun non verbal secara tatap muka. Efektivitas komunikasi antar pribadi yang tinggi di lingkungan kerja akan membuat suasana kerja menjadi menyenangkan sehingga setiap persoalan yang timbul dapat dicarikan jalan keluarnya secara bersama tidak ada lagi salah pengertian atas informasi yang ada diantara individu, yang pada gilirannya akan meningkatkan akan meningkatkan kinerja. Oleh karena itu seorang guru harus mampu meingkatkan efektivitas komunikasi antar pribadi di lingkungan kerjanya karena semakin tinggi efektivitas komunikasi antar pribadi maka akan semakin tinggi pula kinerjanya. Demikian pula sebalikya semakin rendah efektivitas komunikasi antar pribadi maka akan semakin rendah pula kinerjanya.

3. Upaya Peningkatan Motivasi Kerja dan Efektivitas Komunikasi Antar Pribadi dalam Hubungannya dengan Kinerja pada guru Sekolah Dasar Negeri di Lingkungan Kecamatan Bogor Tengah

Perlu adanya upaya peningkatan motivasi kerja dan efektivitas komunikasi antar pribadi di lingkungan kerja. Meningkatkan motivasi kerja dapat 
dilakukan dengan cara mengadakan kegiatan yang berorientasi pada tujuan, kegigihan menyelesaikan pekerjaan, usaha mecapai umpan balik, harapan meraih keberhasilan, keterlibatan dengan tugas yang dikerjakan, kemauan mengembangkan diri yang kesemuanya berhubungan dengan profesi sebagai guru. Demikian juga untuk meningkatkan efektivitas komunikasi antar pribadi dapat dilakukan dengan cara lebih meningkatkan taraf komunikasi berkualitas yang meliputi aspek saling percaya, saling terbuka, tatap muka, saling menghargai, kejelasan pesan yang disampaikan dan umpan balik yang diberikan sehingga masalah-masalah yang timbul dapat diselesaikan bersama. Dengan diterapkan dua hal tersebut di atas maka seorang guru akan lebih termotivasi kerja dan juga akan berkomunikasi secara efektif yang pada gilirannya akan berimplikasi pada peningkatan kinerja secara kuantitas hasil kerja, kualitas hasil kerja, waktu penyelesaian pekerjaan, pencapaian standar kerja dan tanggung jawab terhadap pekerjaan.

\section{REFERENSI}

Amirullah dan Hanafi, R. (2002). Pengantar Manajemen. Yogyakarta: Graha Ilmu.

Angkawijaya, Adam I. (2000). Perlaku Organisasi. Bandung: Sinar Baru Algesindo.

Arep, I. dan Tanjung, H. (2003). Manajemen Motivasi. Jakarta: Gramedia Widia Sarana Indonesia.

Aritonang, Keke T. (2005). Kompensasi Kerja, Disiplin Kerja dan Kinerja Guru SMP Kristen BPK Penabur Jakarta. Jurnal Pendidikan Penabur Jakarta, No 4, Tahun IV.

De Janasz, Suzanne C., et al. (2006). Interpersonal Skills in Organizations. 3rd edition. New York: Mc.Graw Hill Irwing.

Dharma, A. (2003). Manajemen Supervisi. Edisi IV. Jakarta: Penerbit Erlangga.
Effendy, Onong Uchana E. (2003). Komunikasi, Teori dan Praktek. Bandung: PT Remaja Rosdakarya.

Fathoni, A. (2006). Organisasi dan Manajemen Sumber Daya Manusia. Jakarta: PT Rineka Cipta.

Gibson, James L., et al. (2006). Organizations, Behavior, Structure, Processes. New York: McGraw-Hill Irwin.

Gozali, I. (2002). Aplikasi Analisis Multivariat dengan Program SPSS. Semarang: Badan Penerbit Univ. Diponegoro.

Handoko, T. Hani. (2007). Manajemen. Yogyakarta: BPFE.

Hasibuan, Melayu S.P. (2000). Manajemen Sumber Daya Manusia. Jakarta: Bumi Aksara.

Kreitner, R., and Kinicki, A. (2008). Organizational Behavior. Newyork: McGraw-Hill International.

Kydd, L., et al. Professional Development for Educational Management. Jakarta: PT Gramedia Pustaka Utama.

Laporan Dinas Pendidkan Kota Bogor Ujian Akhir Sekolah Berstandar Nasional SD/MI tahun ajaran 2008/2009.

Laporan Kriteria Ketuntasan Minimal Kecamatan Bogor Tengah Tahun 2009.

Mangkunegara, A.A Anwar Prabu. (2007). Evaluasi Kinerja Sumber Daya Manusia. Bandung: PT Rafika Aditama.

Manulang, M. (2001). Manajemen Sumber Daya Manusia. Edisi 1. Yogyakarta: BBPE.

Mathis, Robert L., and Jackson, John H., Human Resource Management Jakarta: Salemba Empat.

Muhamad, A. (2002). Komunikasi dan Organisasi. Jakarta: Bumi Aksara.

Muhidin, Sambas A. dan Abdurahman, M. (2007). Analisis Korelasi, Regresi dan Jalur dalam Penelitian. Bandung: CV Pustaka Setia.

Mulyana, D. (2001). Ilmu Komunikasi Suatu Pengantar. Bandung: PT Remaja Rosdakarya 2001. 
Mulyasa, E. (2002). Manajemen Berbasis Sekolah; Konsep, Strategi dan Implementasi. Bandung: Rosdakarya.

Nawawi, H. (2006). Evaluasi dan Manajemen Kinerja di Lingkungan Perusahaan dan Industri. Yogyakarta: Gajah Mada University Press.

Pidarta, M. (2004). Manajemen Pendidikan Indonesia, Jakarta: Rineka Cipta.

Pradiansyah, A. You Are a Leader. Jakarta: PT Gramedia Pustaka Utama.

Rakhmat, J. (2000). Psikologi Komunikasi. Bandung: Remaja Rosdakarya.

Robbins, Stephen P. (2002). Prinsip-prinsip Perilaku Organisasi Jakarta: PT Gelora Aksara Pratama Erlangga.

Rosyid, Aan H. (2009). Hubungan antara Kepuasan Kerja dan Motivasi Kerha Guru dengan Kinerja Guru. Tesis. Program Pascasarjana Universitas Pakuan.

Rue, Leslie W., and Byars, Lloyd L. (2007). Supervision Key Link to Productivity. NY: McGraw-Hill International Edition.

Ruky, Achmad S. (2002). Sistem Manajemen Kinerja. Jakarta: PT Gramedia Pustaka Utama.

Saputra, Raden Darajat S. (2009). Hubungan antara Komunikasi Interpersonal dan Komitmen Kerja Guru dengan Kinerja Guru. Tesis. Program Pascasarjana Universitas Pakuan.

Siagian, Sondang P. (2002). Manajemen Strategis. Jakarta: Bumi Aksara.

Soeprihanto, J. (2001). Penilaian Kinerja dan Pengembangan Karyawan. Yogyakarta: BPFE Yogyakarta.

Subroto, S. (2002). Proses Belajar Mengajar di Sekolah. Jakarta: Rineka Cipta.

Sugiyono. (2007). Statistik untuk Penelitian. Bandung: Alfabeta.

Thoha, M. (2006). Perilaku Organisasi Konsep Dasar dan Aplikasinya Jakarta: PT Raja Grasindo Persada.

Organisasi. Jakarta: Index.
Veithzal, R. (2004). Manajemen Sumber Daya Manusia untuk Perusahaan. Jakarta: PT Raja Grafindo Persada.

Widjaya, A.W. (2002). Komunikasi dan Hubungan Masyarakat. Jakarta: Bumi Aksara.

- (2000). Pengantar Studi Ilmu Komunikasi. Jakarta: Rineka Cipta.

Winardi. (2002). Motivasi Dan Permotivasian Dalam Manajemen. Jakarta: PT Raja Grafindo Persada.

Wirawan. (2009). Evaluasi Kinerja Sumber Daya Manusia: Teori, Aplikasi, dan Penelitian. Jakarta: Salemba Empat.

Wood, J., et al., (2001). Organization Behaviour: A Global Perspective. New York: United state of America. 